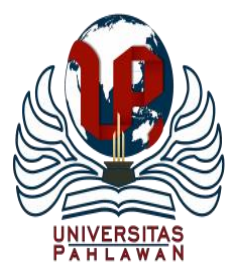

Jurnal Abdidas Volume 2 Nomor 4 Tahun 2021 Halaman 790-800

JURNAL ABDIDAS

http://abdidas.org/index.php/abdidas

\title{
Pemberdayaan Kewirausahaan Santri Pondok Pesantren Ad-Dhuha di Masa Pandemi
}

\author{
Ari Susanti $^{1 \bowtie}$, Budi Istiyanto ${ }^{2}$, Tri Ratna Pamikatsih ${ }^{3}$ \\ Manajemen, Sekolah Tinggi Ilmu Ekonomi Surakarta, Indonesia ${ }^{1,2,3}$ \\ E-mail : $\underline{\text { santisties@gmail.com }}{ }^{1}$ budisties@gmail.com ${ }^{2}$ triratna.pamikatsih@gmail.com $^{3}$
}

\begin{abstract}
Abstrak
Pondok Pesantren Ad-Dhuha merupakan salah pondok pesantren yang memiliki kegiatan kewirausahaan. Dalam pengelolaan bisnisnya, para santri terbiasa untuk melakukan secara offline. Namun akibat terjadi pandemi Covid-19 saat ini, mengharuskan mereka untuk mulai menambah kemampuan yang ada agar mampu bertahan dalam situasi ini. Metode yang digunakan adalah pembekalan materi dan dilanjutkan dengan pendampingan. Pembekalan kewirausahaan dilakukan untuk membuka pandangan para santri mengenai informasi dan langkah yang tepat untuk menjalankan bisnis di era pandemi ini. Pembekalan manajemen operasional dibutuhkan untuk membantu proses produksi agar lebih efisien. Pembekalan pengelolaan keuangan digunakan untuk bagaimana mengelola keuangan dari segi biaya produksi hingga harga jual. Pembekalan pemasaran online dilakukan agar para santri dapat melakukan pemasaran online dengan lebih baik. Hasil dari kegiatan ini, para santri Ad-Dhuha bisa menjalankan bisnis lebih dengan lebih efisien dan baik. Para santri dapat melakukan pemasaran produk mereka secara online dan dapan meningkatkan penjualannya. Sehingga dapat disimpulkan bahwa dari kegiatan pengabdian ini, santri Pondok Pesantren AdDhuha dapat mengahadapi situasi pandemi Covid-19, mampu bertahan dan berjalan lebih efisien dari sebelumnya.
\end{abstract}

Kata kunci: pondok pesantren, pemasaran, operasional, keuangan

\section{Abstract}

Pondok Pesantren Ad-Dhuha is one of boarding schools that has SME's in beverage sector. Usually the student managing their business by offline system. However due to pandemic situation, the student needs to upgrade their existing skills to be able to survive in this situation. the method used is sharing knowledge and continued with mentoring. Students get entrepreneurship to know the information and how to run the business in this pandemic. Operational management is needed to help the production process to be more efficient. Financial management is used for how to manage finances in terms of production costs to selling prices. The student can do better to sell the product with online marketing. As a result, Ad-Dhuha students can run their business more efficiently and well. Students can do their product marketing online and increase their sales. From this program, the business of Pondok Pesantren Ad-Dhua students be able to survive and run more efficiently than before.

Keyword: pondok pesantren, marketing, operational, financial

Copyright (c) 2021 Ari Susanti, Budi Istiyanto, Tri Ratna Pamikatsih

$\triangle$ Corresponding author

Address : Sekolah Tinggi Ilmu Ekonomi Surakarta

ISSN 2721-9224 (Media Cetak)

Email : santisties@gmail.com

ISSN 2721- 9216 (Media Online)

DOI $\quad$ : https://doi.org/10.31004/abdidas.v2i4.367 
791 Pemberdayaan Kewirausahaan Santri Pondok Pesantren Ad-Dhuha di Masa Pandemi - Ari Susanti, Budi Istiyanto, Tri Ratna Pamikatsih

DOI: https://doi.org/10.31004/abdidas.v2i4.367

\section{PENDAHULUAN}

Pondok pesantren merupakan lembaga pendidikan yang dibentuk untuk para santri didik menimba ilmu yang konsep awalnya adalah pengembangan pada ilmu keagamaan. Namun sejalannya waktu maka program yang dibuat adalah bagaimana menciptakan santri yang memiliki kemandirian serta memiliki jiwa berwirausaha. Pengabdian yang dilakukan ini adalah pengabdian yang dilakukan untuk menggali dan membekali para santri dalam melakukan kegiatan kewirausahaan.

Para santri di pondok pesantren ini dilatih bagaimana agar mampu dan siap dalam menciptakan lapangan pekerjaan sendiri nantinya jika sudah menyelesaikan pendidikan. Selain ilmu agama yang dimiliki, maka kesiapan menciptakan lapangan pekerjaan juga sudah disiapkan lebih dini di Pondok pesantren. Pondok pesantren Ad Dhuha merupakan salah satu pondok pesantren yang telah bermitra dengan STIE Surakarta sehingga pengabdian yang dilakukan adalah memberikan pemahaman kepada para santri dan memberikan tambahan keahlian-keahlian tentang pentingnya berwirausaha. Apalagi saat ini perkembangan teknologi yang cukup pesat sehingga kita harus mampu beradaptasi dengan lingkungan yang ada.
Pondok pesantren disebut Lembaga Pendidikan yang berbasis Islam yang mengajarkan ilmu agama sebagai kajian utama dan disiplin dalam penerapan kesehariannya. Perkembangan pondok diawal hanya mendalami ilmu-ilmu agama saja namun sejalannya wakti pondok selalu melakukan inovasi dari fasilitas, anak santri dan kurikulumnya. Kurikulum di pondok pesantren saat ini tidak hanya terbatas pada pengetahuan dan Pendidikan agama namun Pendidikan di pondok pesantren memberikan pelajaran yang berkaitan dengan entrepreneur ataupun kegiatan ekstra seperti di sekolah lainnya. Tujuannya adalah untuk melatih para santri dapat beradaptasi dengan kehidupan bermasyarakat (Komariah, 2016).

Permasalahan yang terjadi dan dihadapi para santri di Pondok Pesantren Ad Dhuha pada masa pandemi adalah bagaimana melanjutkan kegiatan kewirausahaan yang telah dirintis agar tetap bertahan dalam masa pandemic. Para santri menjalankan kewirausahaan dengan berjualan susu kedelai sempat mengalami masalah bagaimana seharusnya yang mereka lakukan dan strategi apa saja yang mereka gunakan agar tetap mampu menjalankan usahanya. Selain itu para santri ingin belajar tentang bagaiaman cara untuk memasarkan secara online dan dapat mengatur keuangan dalam berbisnis dengan baik. 
792 Pemberdayaan Kewirausahaan Santri Pondok Pesantren Ad-Dhuha di Masa Pandemi - Ari Susanti, Budi Istiyanto, Tri Ratna Pamikatsih

DOI: https://doi.org/10.31004/abdidas.v2i4.367

Sasaran kegiatan pengabdian ini adalah meningkatkan pengetahuan para santri yang difokuskan pada masa pandemi ini dalam upaya mempertahankan dan melanjutkan kegiatan kewirausahaan mereka agar tetap bertahap dan berkelanjutan, sehingga para santri mampu menjalankan kegiatannya khususnya dalam menjual susu kedelai tidak hanya di sekitaran pondok tapi bisa sampai ke masyarakat luas, apalagi pada saat ini yang dibutuhkan adalah bahan-bahan alami yang mendukung program kesehatan dalam rangka menjaga imun dan kesehatan di masa pandemi.

Tujuan tim pengabdian dari STIE Surakata mengadakan pengabdian ini akan membahas bagaimana para santri mendapatkan pembekalan kewirausahaan, bagaimana mengelola keuangan dan upaya bagaimana melakukan penjualan dan memasarkan produk yang dihasilkan dengan cara online.

Pandemi yang saat ini terjadi mengharuskan sebagian orang untuk berdiam diri di rumah. Semua kegiatan yang biasa dilakukan diluar rumah, sekarang dilakukan di dalam rumah. Mulai dari bekerja, sekolah hingga berbelanja. Saat ini segala sesuatu dilakukan serba online. Menjadi bagian dari dunia online, bagi sebagian bisnis besar bukanlah hal yang sulit dilakukan. Namun berbeda halnya dengan Usaha Mikro Kecil
Menengah (UMKM) yang terbiasa melakukan penjualan secara offline, mereka akan cenderung bingung mulai darimana untuk memulai bisnis mereka secara online. Hal inilah yang terjadi pada UMKM milik Pondok Pesantren Ad-Dhuha.

Menurut (Susanti, dkk, 2021), bahwa penggunaan media sosial memang perlu ditingkatkan sehingga mampu meningkatkan penjualan karena selama ini banyak yang belum memahami bahwa banyak fasilitas yang tersedi dalam media sosial yang berkaitan dengan penjualan. Di masa pandemi kegiatan yang penjualan berpindah ke kegiatan online, hal ini merupakan perubahan dan inovasi yang digunakan dalam menjalankan suatu usaha.

Menurut (Chotimah, 2015) Jiwa kewirausahaan, inovasai dan kreativitas penting untuk dimiliki karena merupakan kegiatan yang menumbuhkan kemampuan dalam kehidupan manusia. Seeorang pasti memiliki kemampuan untuk berkreativitas namun yang menjadi permasalahan adalah bagaimana menumbuhkan dan mengaplikasikan dalam kegiataan yang nyata dan dikembangkan pembekalan terutama wawasan kewirausahaan dalam Pendidikan khususnya di pondok pesantren.

Salah satu platform yang ada pada google adalah Google Bisnisku, mampu menampilkan posisi tempat usaha menggunakan Gmap/Google Map. Google 
793 Pemberdayaan Kewirausahaan Santri Pondok Pesantren Ad-Dhuha di Masa Pandemi - Ari Susanti, Budi Istiyanto, Tri Ratna Pamikatsih

DOI: https://doi.org/10.31004/abdidas.v2i4.367

sudah terkenal dengan mesin pencarian apa saja, yang terkenal dan sangat mudah digunakan sehingga salah satu fasilitas yang disediakan adalah Google Bisnisku dimana dapat menampilkan posisi tempat dimana usaha kita, digunakan pengembangan usaha dan memudahkan orang lain mencari tentang bisnis yang ada di masyarakat.

Fenomena yang terjadi saat ini adalah adanya masa pandemi Covid-19 dimana para santri menyesuaikan untuk dapat mampu bersaing dalam mempertahankan unit bisnis yang telah ada. Peningkatan skill yang tadinya biasa harus mampu beradaptasi dengan kondisi yang terjadi pada saat ini agar mampu bertahan dengan pemanfaatan teknologi. Dampak dengan adanya masa pandemi ini adalah perubahan dari perilaku hidup bersih dan Kesehatan serta bagaimana upaya untuk dapat terus mempertahankan unit binis yang telah dibentuk. Sehingga pengabdian yang dilakukan oleh Tim Penagbdian dari STIE Surakarta adalah upaya bagaimana pemberdayaan kewirausahaan di pondok pesantren agar mampu mempertahankan unit bisnis yang telah ada dengan beradaptasi dan pemanfataan teknologi yang ada.

\section{METODE}

\section{Waktu Pelaksanaan}

Kegiatan pengabdian pada dasarnya dilakukan selama 2 (dua) hari, namun terkait dengan pendampingan dilakukan selama 3 (tiga) bulan. Kegiatan ini dilakukan pada 13 14 Februari 2021, bertempat di Pondok Pesantren Ad-Dhuha, Sukoharjo Jawa Tengah.

\section{Tahap Persiapan}

Pelaksanaan pengabdian ini dilakukan dengan melakukan komunikasi dengan pengelola pondok pesantren tentang apa saja permasalahan yang dihadapi khususnya selamam masa pandemi. Informasi yang diberikan oleh pengurus pesantren adalah terutama dalam pengelolaan kewirausahaan para santri yang sudah dijalankan sebelumnya membutuhkan suatu inovasi cara memasarkan dan membutuhkan pembekalan bagaimana melakukan perencanaan keuangan yang benar agar tetap mampu mengelola keuangan pada masa saat ini. Setelah komunikasi dan diskusi dilakukan akhirnya tim pengabdian dan pengurus pondok pesantren sepakat untuk mengambil beberapa tema dan kegiatan untuk melakukan pembekalan kepada para santri.

\section{Tahap Pelaksanaan}

Pelaksanaan kegiatan pengabdian ini dilakukan perpaduan antara bagaimana mengembangkan usaha yang telah ada sehingga diadakan workshop berupa penjelasan materi, selanjutnya para santri langsung mempraktekan bagaimana caranya mengoperasikan Google My Business untuk 
794 Pemberdayaan Kewirausahaan Santri Pondok Pesantren Ad-Dhuha di Masa Pandemi - Ari Susanti, Budi Istiyanto, Tri Ratna Pamikatsih

DOI: https://doi.org/10.31004/abdidas.v2i4.367

mempromosikan usahanya sebagai peningkatan penjualan.

Kegiatan ini dilakukan selama 2 (dua) hari. Uraian kegiatannya adalah sebagai berikut:

Pelaksanaan Hari pertama:

1. Pembekalan kewirausahaan - materi ini diberikan untuk menambah pengetahuan para santri. Para santri telah memiliki bekal dalam pelaksanaan usaha yang telah dijalankan namun sejalannya waktu pada santri membutuhkan tambahan ilmu yang memiliki kebaharuan sehingga tidak ketinggalan dengan adanya informasi bagaimana kewirausahaan yang tepat dalam masa pandemi seperti ini. Apalagi banyak kegiatan pada masa pandemi ini dibatasi, untuk keluar masuk pondik juga dengan menggunakan syarat yang ketat. Para santri telah menjalankan jual beli produk yang ada di sekitaran lingkungan pondok. Pembekalan kewirausahaan ini adalah sebagai upaya peningkatan penjualan walaupun masa pandemi seperti ini.

2. Pembekalan Manajemen Operasionalmateri ini diberikan bagaimana pengelolaan mulai dari memproduksi sampai cara pengemasan yang baik. Produksi yang dihasilkan masih dalam skala kecil sehingga proses produksi dalam materi ini menjelaskan bagaimana cara memperoleh bahan baku, proses pembuatan dan pengemasannya. Pertimbangan manajemen operasional yang tepat akan mampu bersaing dengan produk lain di pasaran.

\section{Pelaksanaan Hari Kedua}

1. Pengelolaan Keuangan-materi yang disampaikan adalah sesuai dengan permintaan para santri yang selama ini telah menjalankan usahanya. Seringkali bisnis yang dijalankan tanpa ada pencatatan saat membeli baha baku, memproses sampai menjual. Sehingga disini yang penting adakah mampu memproduksi setiap harinya. Oleh karena itu maka diberi penjelasan tentang bagaimana cara menghitung, menentukan biaya-biaya yang digunakan dari awal produksi sampai dengan menentukan harga jual. Apalagi pada saat pandemi seperti ini banyak yang beralih ke minuman yang memiliki gizi tinggi sehingga ini merupakan peluang dari para santri dalam pengembangan usahanya.

2. Pemasaran online-materi pemasaran yang diberikan mengarah ke pemasaran online, dimana penggunaan Google My Business agar mempermudah para santri dalam melakukan pemasaran. Selain itu bisa juga sebagai media pemasaran yang 
795 Pemberdayaan Kewirausahaan Santri Pondok Pesantren Ad-Dhuha di Masa Pandemi - Ari Susanti, Budi Istiyanto, Tri Ratna Pamikatsih

DOI: https://doi.org/10.31004/abdidas.v2i4.367

tidak hanya melakukan pemasaran di sekitaran pondok pesantren namun bisa dipasarkan ke wilayah yang lebih luas dan terjangkau.

\section{Tahap Tindak Lanjut}

Proses selanjutnya dari tim pengabdian adalah melakukan pendampingan terhadap para santri yang telah diberikan pembekalan tentang kegiatan pemberdayaan kewirausahaannya. Berdasarkan pembekalan materi yang diberikan tim pengabdian melakukan pendampingan sesuai dengan bidangnya masing-masing-masing. Agar bisa mengarahkan bagaimana operasional mulai bahan baku, proses dan produk jadi. Kemudian memperhitungkan keuangannya, penyusunan anggaran, perencanaan keuangan, harga jual. Serta pendampingan terhadap penggunaan aplikasi dari google yaitu Google My Business dimana nanti jangkauan pemasaran, media yang digunakan dalam pemasaran serta pengembangan bisnis yang dilakukan.

\section{Tahap Pendampingan Dan Evaluasi}

Pada kegiatan ini, pendampingan pengabdian dilakukan kepada para santri. Pendampingan dilakukan oleh tim pengabdian tentang pembekalan kewirausahaan, manajemen operasional dan pengelolaan keuangan. Untuk pemasaran maka dilakukan pendampingan dengan adanya permasalahan para santri yang sulit dalam melakukan penjualan offline pada masa pandemi, maka mau tidak mau para santri harus mulai memulai penjualan mereka secara online. Salah satu langkah yang mereka bisa lakukan adalah memanfaatkan fitur yang ditawarkan oleh Google, yaitu Google My Business. Google My Business atau yang biasa dikenal dengan istilah Google Bisnisku merupakan suatu platform yang ditawarkan Google untuk para UMKM untuk memperkenalkan bisnis mereka secara luas. Evaluasi yang kami dapat adalah setelah pendampingan dilakukan proses evaluasi kegiatan. Pendampingan akan terus berlanjut dan tim pengabdian akan siap mengunjungi melihat dan para santri bisa berkonsultasi permsalahan-permasalahan yang mereka hadapi.

\section{HASIL DAN PEMBAHASAN}

Pelaksanaan pengabdian ini dilakukan dengan tujuan utama agar para santri mampu menjalankan kegiatan kewirausahaan yang telah dirintisnya. Adanya masa pandemi ini maka berdampak terhadap keinginan tahu para santri tentang pengetahuan santri bagaimana caranya menjalani masa ini dan tetap berwirausaha. Tim Pengabdian melakukan motivasi dalam kegiatan ini. Sehingga upaya yang dilakukan membuat para santri antusias dalam mengikuti kegiatan ini. 
796 Pemberdayaan Kewirausahaan Santri Pondok Pesantren Ad-Dhuha di Masa Pandemi - Ari Susanti, Budi Istiyanto, Tri Ratna Pamikatsih

DOI: https://doi.org/10.31004/abdidas.v2i4.367

Pelaksanaan pengabdian dilakukan selama 2 (dua) hari dan selanjutnya dilakukan pendampingan. Kewirausahaan yang telah dilaksanakan oleh para santri yang sedang menempuh sekolah menengah atas. Dalam rangka pemberdayaan kewirausahaan ini membuat para santri menumbuhkan semangat dalam berwirausaha. Masa pandemi ini menurut mereka masa yang harus dilalui namun membutuhkan tips dan trik agar termotivasi untuk melakukan kegiatan wirausaha ini. Produk yang dihasilkan oleh para santri ini adalah susu kedelai. Tim pengabdian mengajak para santri untuk tetap produktif di masa pandemi karena justru ini merupakan peluang dalam peningkatan kegiatan kewirausahaan yaitu menjual susu kedelai tersebut. Susu kedelai menjadi pilihan di masa pandemi ini karena merupakan bahan alami yang mengandung banyak gizi. Masyarakat saat ini lebih memandang susu olahan lainnya seperti berbahan dari susu sapi, padahal susu kedelai juga mengandung gizi yang tinggi. Maka kita mengarahkan untuk tetap dapat melakukan produksi dan mampu melakukan pendeketan kemasyarakat tentang kandungan dari susu kedelai tersebut.

Manajemen operasional untuk produksi susu kedelai, para santri masih menghasilkan jumlah sedikit hal ini bahan baku hanya mengandalkan dari berbelanja di pasar terdekat dan kebutuhan lainnya di lokasi terdekat. Hal ini karena santri hanya memproduksi dengan jumlah terbatas. Sehingga pada kesempatan ini kami mengarahkan untuk mencoba menganalisis permintaan pasar pada saat ini, tidak hanya menjual di sekitaran tapi dimulai dilakukan pemasaran secara online melalui media social atau WA. Sehingga memiliki langganan tetap yang berada di sekitaran pondok pesantren. Pada manajemen operasional dijelaskan oleh tim pengabdian tentang bagaimana pengembangan proses produksi susu kedelai, menciptakan inovasi produk yang lebih menarik dengan adanya varian rasa misalnya melon, strawberry. Materi juga diberikan terkait dengan bagaimana mempersiapkan stok dan peralatan yang efisien dalam melakukan proses produksi sampai nanti pengemasan.

Pada pelaksanaan hari kedua para santri diajarkan cara mengelola keuangan. Selama ini usaha penjualan susu kedelai yang dijalankan adalah yang penting bisa berjalan setiap harinya. Namun para santri mau mempelajari bagaimanakah mengelola keuangan yang baik dan benar sehingga pencatatannya bisa terekam dengan baik. Sehingga dari hasil penjualan susu kedelai tersebut bisa menjadikan lahan usaha mereka untuk menciptakan pekerjaan khususnya untuk para santri. Materi yang diberikan adalah diajarkan bagaimana pencatatan keuangan yang harus dilakukan. Penganggaran terhadap 
797 Pemberdayaan Kewirausahaan Santri Pondok Pesantren Ad-Dhuha di Masa Pandemi - Ari Susanti, Budi Istiyanto, Tri Ratna Pamikatsih

DOI: https://doi.org/10.31004/abdidas.v2i4.367

pembelian bahan baku, proses peramalan penjualan juga dijelaskan oleh tim pengabdian.

Materi selanjutnya adalah memberikan penjelasan tentang bagaimana pengelolaan pemsaran yang awalnya hanya di sekitaran pondok, diajarkan bagaimana mereka menggunakan Google My Business untuk nantinya menjadi bekal mereka memasarkan produk atau nanti bisnis lainnya. Santri dari Pondok Pesantren Ad-Dhuha menjual berbagai hasil kerajinan mereka, mulai dari produk sehari-hari hingga makanan. Namun saat pandemi sekarang ini, mengharuskan mereka untuk berhenti berproduksi, dikarenakan para santri terbiasa untuk melakukan penjualan secara offline. Dengan ada pembatasan sosial yang diterapkan saat ini, menjadikan penjualan secara offline sulit dilakukan.

Salah satu pengenalan yang dilakukan adalah Google My Business memberikan kemudahan kepada santri Ad-Dhuha untuk memunculkan usaha mereka pada Google Search dan Google Maps yang mencakup informasi mengenai nama bisnis mereka, lokasi usaha hingga jam operasional.

Manu \& Fallo, 2019 dalam penelitiannya menggunakan platform gratis dari google yaitu google my business yang digunakan oleh pemikik bisnis untuk melakukan manajemen lokasi bisnisnya yang terintegrasi dengan Google Maps. Pengusaha yang akan melakukan bisnis dengan mudah mendaftar tanpa dipungut biaya di Google My Business dan diakses melalui website yaitu https://www.google.com/business.

Dengan menggunakan Google My Business, maka santri Ad-Dhuha memberi kemudahan kepada calon konsumen untuk mendapatkan informasi mengenai bisnisnya. Selain memudahkan calon konsumen mendapatkan informasi mengenai bisnis yang ditawarkan santri Ad-Dhuha, ada beberapa keuntungan lain yang diberikan ketika menggunakan Google My Business, antara lain:

1. Meningkatkan visibilitas pencarian bisnis Keuntungan terbesar dalam menggunakan Google My Business adalah bisnis dari santri Ad-Dhuha lebih mudah ditemukan atau dicari secara online. Biasanya seorang konsumen, mereka akan mencari produk yang mereka cari yang ada disekitar mereka menggunakan Google Search. Dapat kita ambil contoh, ketika kita menuliskan di Google Search, "rumah makan di daerah Makam Haji, Solo" maka Google akan memberikan daftar rumah makan di daerah Makam Haji, Solo. Berdasarkan hasil pencarian tersebut. Google akan menampilkan 3 (tiga) rumah makan teratas berdasarkan hasil tersebut merupakan rumah makan yang memiliki Google My Business. Dengan demikian, calon konsumen akan 
798 Pemberdayaan Kewirausahaan Santri Pondok Pesantren Ad-Dhuha di Masa Pandemi - Ari Susanti, Budi Istiyanto, Tri Ratna Pamikatsih

DOI: https://doi.org/10.31004/abdidas.v2i4.367

lebih mudah mengetahui mengenai keberadaan rumah makan tersebut berdasarkan Google My Business.

2. Membangun kepercayaan konsumen

Google My Business memberikan fitur review atau ulasan dari konsumen terhadap produk yang dijual. Ulasan positif mengenai produk yang dijual akan meningkatkan kepercayaan calon konsumen lainnya. Pada umumnya konsumen online cenderung akan mencari ulasan mengenai suatu produk sebelum memutuskan untuk membelinya. Ulasan dari konsumen juga akan membantu meningkatkan brand awareness, yang nantinya akan meningkatkan kredibilitas dari bisnis tersebut.

\section{Meningkatkan penjualan}

Ulasan positif dari konsumen tidak hanya meningkatkan kepercayaan saja, namun juga meningkatkan penjualan. Dengan ulasan positif, maka konsumen tidak akan segan-segan membeli produk yang ditawarkan. Konsumen memiliki kecenderungan mempercayai ulasan positif dari produk tersebut. Semakin banyak ulasan positif, maka semakin besar peluang untuk peningkatan penjualan.

Namun dalam suatu bisnis bukan hal yang tidak mungkin bahwa ada beberapa konsumen yang tidak puas dengan produk yang dijual dan mereka memberikan ulasan negatif. Ketika hal ini terjadi, maka yang harus dilakukan adalah menangani ulasan negatif ini dengan bijaksana dan profesional. Ulasan negatif yang diberikan dapat digunakan untuk meningkatkan kemajuan produk atau bisnis tersebut.

4. Mengurangi biaya promosi

Promosi biasanya merupakan hal yang sangat krusial dari sebuah bisnis. Promosi biasanya akan memakan biaya yang cukup besar. Google My Business menawarkan promosi dengan cara yang lebih mudah dan murah. Google My Business memberikan layanan pembuatan website secara gratis. Dengan memanfaatkan fitur ini, maka santri AdDhuha dapat mengurangi biaya promosi.

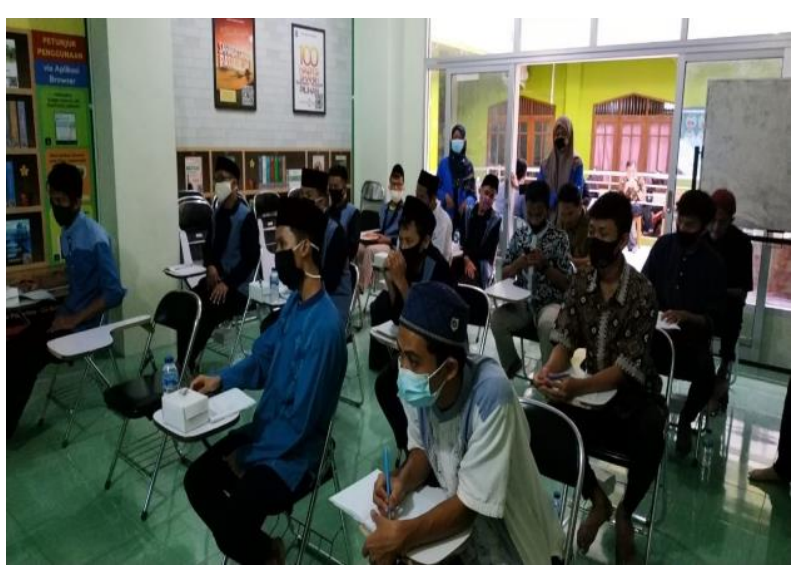

Gambar 1. Para Santri Mengikuti Kegiatan Pengabdian 
799 Pemberdayaan Kewirausahaan Santri Pondok Pesantren Ad-Dhuha di Masa Pandemi - Ari Susanti, Budi Istiyanto, Tri Ratna Pamikatsih

DOI: https://doi.org/10.31004/abdidas.v2i4.367

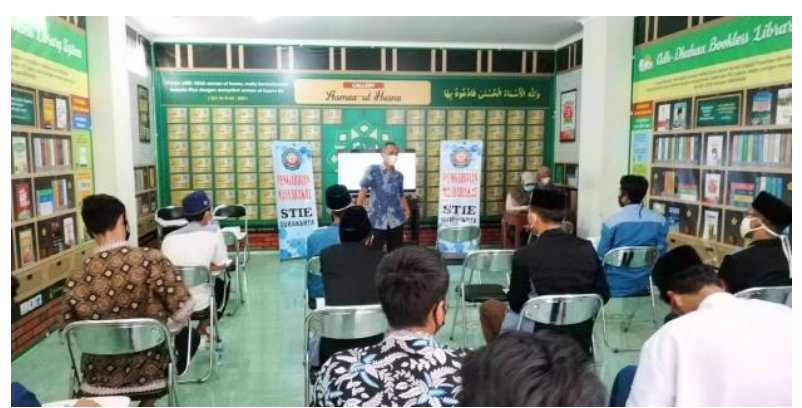

Gambar 2. Pemateri Google My Business

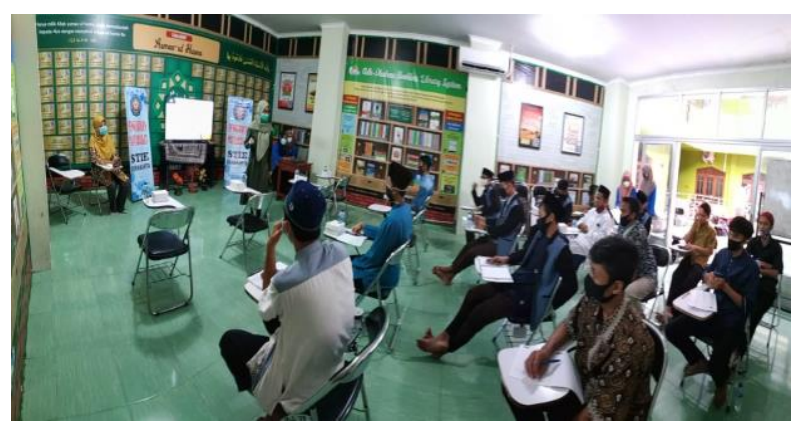

Gambar 3. Pemberian Materi Kewirausahaan

S

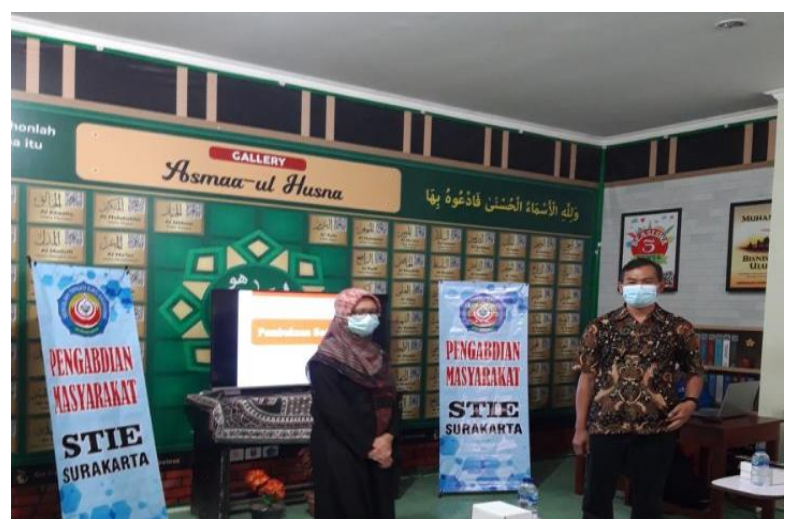

Gambar 4. Pemberian Materi Pengelolaan Keuangan

\section{SIMPULAN}

Pondok Pesantren Ad-Dhuha merupakan salah satu pondok pesantren yang telah bermitra dengan STIE Surakarta. Santri pada pondok pesantren ini sebelumnya telah memiliki bisnis, namun dalam pelaksanaannya masih menggunakan sistem offline. Sehingga dalam menghadapi situasi pandemi covid-19 ini, sedikit mengalami kendala.

Program pengabdian yang telah dilakukan ini merupakan salah satu langkah yang dapat dimanfaatkan para santri untuk meningkatkan kemampuan dari santri pondok Pesantren Ad-Dhuha. Program ini dimulai dengan pemberian pemahaman mengenai kewirausahaan. Pemahaman kewirausahaan ini membuka pandangan santri terhadap bagaimana menjalankan bisnis dengan baik dan memberikan informasi-informasi yang dapat dimanfaatkan para santri untuk menjalankan bisnisnya. Selanjutnya pembekalan yang didapatkan para santri adalah manajemen operasional. Dari pembekalan ini para santri menjadi lebih memahami bagaimana melakukan proses produksi dari hulu sampai hilir dengan cara yang efisien. Pengelolaan keuangan juga diberikan dalam program pengabdian ini. Dengan pengelolaan keuangan yang baik, maka santri dapat menetukan biaya awal hingga harga jual dengan tepat. Pembekalan yang terakhir adalah pemasaran online, yang berfokus pada Google My Business. Pemasaraan online ini diharapkan dapat membantu para santri dengan memasarkan produknya secara lebih luas dengan biaya yang murah. Setelah adanya pembekalan dari 
800 Pemberdayaan Kewirausahaan Santri Pondok Pesantren Ad-Dhuha di Masa Pandemi - Ari Susanti, Budi Istiyanto, Tri Ratna Pamikatsih

DOI: https://doi.org/10.31004/abdidas.v2i4.367

beberapa materi, maka diakan pendampingan kepada para santri.

Dengan terlaksana program ini, diharapkan unit bisnis santri Ad-Dhuha dapat bertahan dalam situasi pandemi covid-19. Selain bertahan dalam situasi ini, diharapkan unit bisnis santri dapat berjalan lebih baik dari segi pemasaran dan keuangannya.

\section{UCAPAN TERIMA KASIH}

Terima kasih kepada Tim Pengabdian STIE Surakarta dan Pondok Pesantren Ad Dhuha dan para santri yang telah memberikan kesempatan kepada kami untuk berbagi keilmuan pada kegiatan ini.

\section{DAFTAR PUSTAKA}

Chotimah, C. (2015). Pendidikan Kewirausahaan Di Pondok Pesantren Sidogiri Pasuruan. Inferensi, 6(2), 114. https://doi.org/10.18326/infsl3.v8i1.114136

Dwiarta, I. M. B., \& Chusnul, C. (2017). I Made Bagus Dwiarta Chusnul Choiria. Penamas Adi Buana, 01.

Manu, G. A., \& Fallo, D. (2019). Implementasi Google My Business (Gmb) Dalam Promosi Pariwisata Di Kota Kupang Dan Sekitarnya. Jurnal Pendidikan Teknologi Informasi (JUKANTI), 2(2), 8-15. https://doi.org/10.37792/jukanti.v2i2.69

Komariah, Nur, 2016. Pondok Pesantren Sebagai Role Model Pendidikan Berbasis Full Day School. Hikmah: Jurnal Pendidikan Islam. Fakultas Agama Islam (FAI) Universitas Islam Indragiri HIKMAH: Jurnal Pendidikan Islam Vol.
5, No. 2, Juli - Desember 2016. 5(2), 221-240.

Susanti, A, Ria Estiana, Yopy Ratna Dewanti, A. S. (2021). Strategi Perencanaan Keuangan Untuk Penjualandan Pajak Umkm Di Masa Pandemi. Jurnal Pengabdian Kepada Masyarakat, 2(Vol. 2 No 1, January 2021, pp. 277-283), 277-283. https://doi.org/10.31949/jb.v2i1.731

SIPAYUNG, E., \& PRIYANTO, S. H. (2019). Analisis Komunikasi Pemasaran Dalam Menarik Pengunjung (Studi Pada Kampoeng Kopi Banaran, Pt. Perkebunan Nusantara Ix Kabupaten Semarang). Jurnal Ilmiah Agrineca, 19(2), 55-66. https://doi.org/10.36728/afp.v19i2.901 